\title{
How to Plan Lessons in the New Normal Education: A Reintroduction to Selected Instructional Design Processes
}

\author{
Michael Bobias Cahapay ${ }^{1 *}$
}

${ }^{1}$ College of Education, Mindanao State University, General Santos City, PHILIPPINES

*Corresponding Author: mbcahapay@up.edu.ph

Citation: Cahapay, M. B. (2021). How to Plan Lessons in the New Normal Education: A Reintroduction to Selected Instructional Design Processes. Aquademia, 5(1), ep21006. https://doi.org/10.21601/aquademia/10807

\section{ARTICLE INFO}

Received: 13 Aug. 2020

Accepted: 27 Oct. 2020

\begin{abstract}
Amid the continuing risks posed by the Coronavirus Disease 2019 (COVID-19) crisis, teachers are in a state of a predicament as schools have reopened. A problem that has been often raised is how to plan the lessons in the context of 'new normal' education. The answer lies in some extant instructional design processes which may have not only been given purposeful attention since the past up to the recent scholarly discussions. Thus, this article reintroduces these selected instructional design processes that may assist the teachers in planning their lessons in the new normal education. The researcher discusses unpacking the curriculum standards, designing the events of instruction, selecting instructional materials, and using constructive alignment. These selected instructional design processes are expected to bring about better responses, thus improve the current work of the teachers in the field amid the tough period.
\end{abstract}

Keywords: instructional design, curriculum development, education, new normal, COVID-19

\section{INTRODUCTION}

One of the sectors overwhelmingly affected by the COVID19 global crisis and is continuously facing emerging challenges is the education sector. The current crisis from the educational perspective is a colossal transformative challenge because it has no readily defined guide for an appropriate response (Organization for Economic Cooperation and Development, 2020). As such, the education authorities are expected to efficiently develop applicable responses on a trial-and-error basis amid the crisis as schools have reopened.

One timely question posed by Daniel (2020) as regards the curriculum is: What curriculum should teachers use for remote learning during the COVID-19 crisis? This question presents a real concern, but from a curriculum studies perspective, the primary focus of teachers should be on the instruction. The expectations as embodied in the curriculum must remain the same. An aspect that needs immediate attention is the instruction. This tall order presents a challenge for the elements of instruction: objectives, topics, teaching strategies, and assessment tasks. The orderly process of developing these elements of instruction, which are usually embodied in the lesson plans, is called instructional design (Merrill et al., 1996).

A large body of recent educational discussions has reconsidered the future of education amid the crisis. Most have focused on the challenges and opportunities of remote education in particular (e.g., Adedoyin \& Soykan, 2020; Donitsa-Schmidt \& Ramot, 2020; Liguori \& Winkler, 2020; Sepulveda-Escobar \& Morrison, 2020). However, the processes specifically used in instructional design, which have practical significance to the situation, appear to be overlooked in the current educational conversations.

As education authorities scramble at testing new waters within the challenges and opportunities of the moment, this paper believes that the solution lies in the extant instructional design processes which have only not been given direct attention in the teaching practices. Drawing from professional experience, this paper presents four instructional design processes that can be used by teachers as they plan their lessons in the new normal education. These instructional design processes include unpacking of curriculum standards, designing the events of instruction, selecting instructional materials, and using constructive alignment.

A revisit of some essential instructional design processes is significant as it will offer a practical guide to school administrators and teachers who are positioned at the fore of education amid the current crisis. It will rekindle extant but apparently covert practices that may lead to better responses, thus lighten the impact of the crisis. Considering this point, the main purpose of this article is to reintroduce selected instructional design processes that may assist the teachers in planning their lessons in the new normal education. 
Table 1. Levels of cognitive domain based on Bloom (1956)

\begin{tabular}{lll}
\hline Level & Description & Verbs \\
\hline 6. Synthesis & Put elements together to form a new whole & $\begin{array}{l}\text { compose, create, develop, devise, formulate, generate, produce, propose, } \\
\text { synthesize, write }\end{array}$ \\
\hline 5. Evaluation & $\begin{array}{l}\text { Make judgments based on criteria and } \\
\text { standards }\end{array}$ & $\begin{array}{l}\text { appraise, argue, assess, critique, evaluate, grade, judge, justify, rate, review, } \\
\text { support, test, validate }\end{array}$ \\
\hline 4. Analysis & Break the material into its constituent parts & $\begin{array}{l}\text { analyze, arrange, connect, deconstruct, diagram, discriminate, distinguish, } \\
\text { order, organize, relate }\end{array}$ \\
\hline 3. Application & Use information or skill in a new situation & $\begin{array}{l}\text { apply, compute, dramatize, examine, execute, experiment, implement, } \\
\text { manipulate, solve, use }\end{array}$ \\
\hline 2. Understanding & Demonstrate forms of comprehension & $\begin{array}{l}\text { classify, compare, conclude, describe, explain, generalize, infer, interpret, } \\
\text { predict, summarize }\end{array}$ \\
\hline 1. Knowledge & Recall knowledge from the long-term memory & $\begin{array}{l}\text { define, identify, label, list, match, name, outline, quote, recall, report, } \\
\text { reproduce, show, state }\end{array}$ \\
\hline
\end{tabular}

\section{REINTRODUCTION TO SELECTED INSTRUCTIONAL DESIGN PROCESSES}

The researcher in this article presents four essential instructional design processes that may be useful in planning lessons especially in times when we are overwhelmed by great educational changes amid the COVID-19 crisis. These processes are unpacking of curriculum standards, designing the events of instruction, selecting instructional materials, and using constructive alignment. They are discussed as follows.

\section{Unpacking the Curriculum Standards}

The process of "unpacking" in the context of curriculum studies may be defined as the process of translating the intended curriculum into instruction (Cahapay, 2020). The intended curriculum here is often represented by standards, hence the common educational phrase "unpacking the curriculum standards." On the other hand, standards are broad statements that in the many curriculum contexts may refer to the outcomes, competencies, or goals.

As teachers go through planning the lesson, an initial process from which they must begin is to unpack the curriculum standards into instructional objectives. While curriculum unpacking seems common, it is observed in practice that what some teachers do not realize is the hierarchical relationship between the curriculum standards and instructional objectives. Assuming that the curriculum standard is correctly formulated, the task of unpacking them is by examining what instructional objective at the lower level will achieve it.

An important tool that is used in this process is the taxonomy of the cognitive domain originally devised by Bloom (1956). It consists of six levels in hierarchical nature: synthesis, evaluation. When applied in the unpacking process, the curriculum standards are framed in the higher level order thinking skills. On the other hand, the instructional objectives are expressed in the lower order thinking skills or equal to the set level of curriculum standards. These levels of the cognitive domain are further presented in Table 1.

For example, in unpacking a curriculum standard at the higher level "write real and fictional short stories with complete key elements" (synthesis level) the teacher must break down this standard into lower level tasks or lesson objectives required to achieve this stated curriculum standard.
Thus, based on this example, lesson objectives that may be unpacked are "critique a short story based on the required key elements" (evaluation level) or "examine the key elements of a short story" (analysis level). The cogent principle behind this process is that, for example, how can we expect the learners to write real and fictional short stories with complete key elements if they do not know how to evaluate, examine, analyze, understand or remember the elements in the first place? This detail is usually in which many unpacking errors occur.

\section{Designing the Events of Instruction}

The instructional design has several aspects and an important aspect is designing its events of instruction. Whether such an instruction is delivered in a face-to-face or remote modality, certain principles that underlie the instruction remain constant.

One of the instructional design models focused on designing the events of instruction was developed by Gagne (1965) known as "Nine Events of Instruction." This instructional design model is appropriate for difficult lessons in which learners have no considerable prior knowledge and that require a step-by-step process. Designing the parts of your lesson plan, online class, or print module following the events of instruction of this model should more or less consider the following instructional events shown in Figure 1. Each event would require teachers to think of instructional methods or strategies to achieve it.

Another recommended instructional design model that is focused on developing the events of instruction is the "Instructional Theory into Practice" model by Hunter (1989). This direct instruction model underscores that no matter what teaching style, grade level, subject matter, or student background, effective instruction contains eight events that improve learning. These events of instruction are anticipatory set, stating the objectives, instructional input, modeling, check for understanding, guided practice, and closure. These events of instruction consist of parts of a lesson plan, a series of online activities, or a print module.

A relatively recent instructional design model is the 5Es model developed by a team led by Bybee (2009). The name of the model represents the five instructional events: engage, explore, explain, elaborate, and evaluate. It is a learning cycle that is based on a constructivist view of learning, thus places students at the center of their learning experiences. Whether 


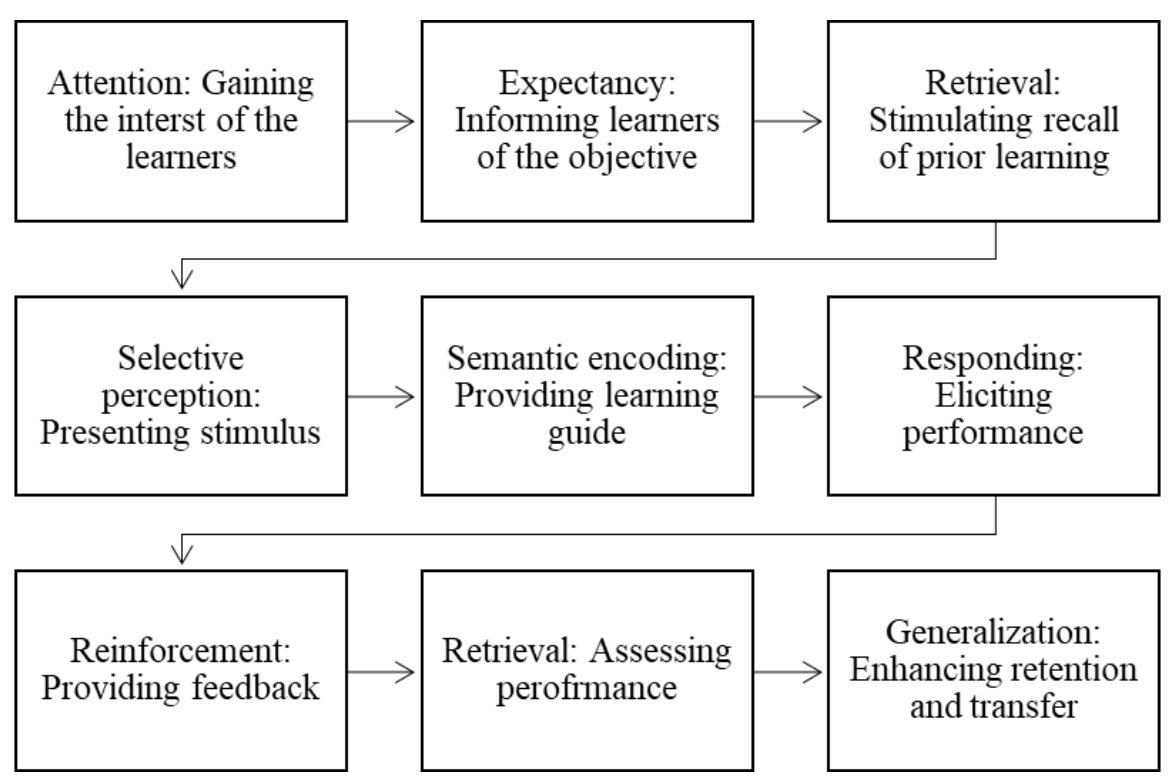

Figure 1. Events of instruction based on Gagne (1963)

embodied in face-to-face, remote, or print modular instruction, this instructional design model provides students with experiences that would challenge their current conceptions or prior knowledge and ample time and activities that would facilitate the reconstruction of their ideas.

It should be carefully noted that the events in these instructional design models in their entirety should be regarded as one form of instructional strategy and the order of events can be altered and not all events need be present in every lesson. Teachers can combine, eliminate, or exchange steps as required. Furthermore, when selecting what model to adopt, the teachers should consider the nature of the lesson and the capacity of the learners.

\section{Selecting Instructional Materials}

Whether your school will be adopting a modular instruction, television- or radio- based instruction, or online instruction, the instructional materials should be generally selected in terms of pedagogical and practical characteristics. There are exhaustive standards for selecting instructional materials. Print (1993) was more precise in his presentation of these standards in light of choosing the most appropriate instructional materials. He offered the following:

1. Interest means that the materials catch and hold interest, and stimulate the curiosity of the learners, and can be used to satisfy curiosity.

2. Authenticity means that materials are factually accurate and up to date, and producer and author are well qualified to devise such.

3. Appropriateness means that materials are suited with respect to vocabulary level, concept difficulty, development methods.

4. Technical quality means that materials satisfy visual imagery, sounds are intelligible, color used effectively, visual and sound synchronize.

5. Organization and balance mean that materials are presented following principles of learning, logically and clearly, and imaginatively.
Whichever instructional modality, the following types of instructional materials, their descriptions, and common examples adopted from the review of Ellington (1987) may be screened using the standards for selecting instructional materials discussed. It includes extremely practical but often neglected items. They are presented in Table 2.

\section{Using Constructive Alignment}

A well-designed instruction, for one, has aligned components. The alignment of the components of instruction may be guided by the process of constructive alignment. Whether you are in the planning phase or evaluation phase of instructional development, constructive alignment is an effective guide to make sure that the instructional components match with each other. The heart of constructive alignment lies in making the learning objective, teaching strategies, and assessment tasks coherent (Biggs et al., 2011).

A cogent process that is guided by the use of constructive alignment begins with the formulation of the learning objective. We have discussed earlier how a learning objective can be unpacked from the curriculum standards. Based on the cognitive demand of the learning objective, the assessment task is designed. Then, once the assessment task has been designed, the activities are organized to teach the learners how to meet the assessment task and thus the learning objective. An example is adapted in Table 3.

Looking at the example, the learning objective is stated as "To identify the main signs of multiple sclerosis." Take note that the cognitive demand of this learning objective is knowledge level. Based on this cognitive demand, an appropriate assessment task is a multiple choice since it requires the identification of correct answers, which in this case, are the main signs of autism spectrum disorder. Then, based on this assessment task, the activities that may be organized are game, lecture, and exercise which all focus on identifying the main signs of autism spectrum disorder. 
Table 2. Types of instructional materials based on Ellington (1987)

\begin{tabular}{|c|c|c|}
\hline Types & Description & Examples \\
\hline $\begin{array}{l}\text { Printed and } \\
\text { duplicated }\end{array}$ & $\begin{array}{l}\text { Textual and other materials that can be run in large numbers on } \\
\text { a duplicate or printing machine for use by students. }\end{array}$ & $\begin{array}{l}\text { handouts, assignment sheets, individualized learning } \\
\text { materials, resource materials for group exercises, }\end{array}$ \\
\hline $\begin{array}{l}\text { Non projected } \\
\text { display }\end{array}$ & $\begin{array}{l}\text { Visual display materials that can be shown to a class, small } \\
\text { group, or individual student without the use of an optical or } \\
\text { electronic projector of any sort. }\end{array}$ & $\begin{array}{l}\text { Chalkboard, markerboard, felt board, magnetic board, } \\
\text { charts, posters, photographs, mobiles, models, } \\
\text { diorama, realia }\end{array}$ \\
\hline $\begin{array}{l}\text { Still projected } \\
\text { display }\end{array}$ & $\begin{array}{l}\text { Visual display materials which cannot incorporate movement } \\
\text { and which require an optical projector to show them to a class or } \\
\text { group or enable them to be studied by a learner. }\end{array}$ & $\begin{array}{l}\text { Overhead transparencies, slides, filmstrips, } \\
\text { microforms }\end{array}$ \\
\hline Audio & $\begin{array}{l}\text { Various systems whereby straightforward audio signals can be } \\
\text { played to a class or group or listened by an individual. }\end{array}$ & Radio broadcasts, gramophone records, audiotapes \\
\hline $\begin{array}{l}\text { Linked audio and } \\
\text { visual }\end{array}$ & $\begin{array}{l}\text { Audio and visual combined to form integrated instructional } \\
\text { systems particularly suitable for use in individualized learning }\end{array}$ & $\begin{array}{l}\text { Tape-slide programs, tape-photographs programs, } \\
\text { radiovision programs, filmstrips with sound, tape-text, } \\
\text { tape-model }\end{array}$ \\
\hline Video & $\begin{array}{l}\text { Media that enable audio signals to be combined with moving } \\
\text { visual sequences, thus enabling a further dimension to be added } \\
\text { to integrated audiovisual presentations }\end{array}$ & $\begin{array}{l}\text { Cine films, loop films, tape-films programs, television } \\
\text { broadcast, videotape recording, videodisc recording }\end{array}$ \\
\hline Computer mediated & $\begin{array}{l}\text { Various materials that require a computer of some sort to enable } \\
\text { them to be displayed, studied or, used }\end{array}$ & $\begin{array}{l}\text { Data processing packages, 'substitute tutor' packages, } \\
\text { 'substitute laboratory’ packages, database systems, } \\
\text { computer learning system, interactive video system }\end{array}$ \\
\hline
\end{tabular}

Table 3. Example of how the components can be aligned

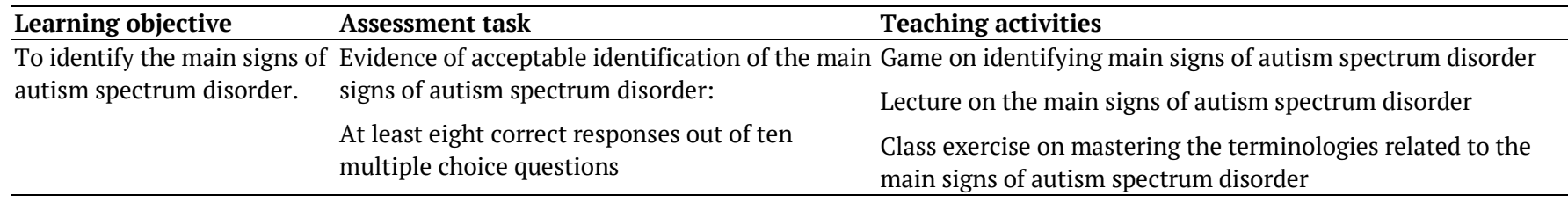

\section{CONCLUSION}

It cannot be denied that the COVID-19 crisis has presented education with a great challenge. Teachers are heard to ask how to design instruction in the context of new normal education. While answers are currently being experimented, some extant instructional design processes present opportunities to answer such a predicament of the teachers. This article was anchored on this motivation, thus it attempted to reintroduce some of these essential instructional design processes that may assist the teachers in planning their lessons in the new normal education.

This paper discussed the instructional design processes that can be applied in planning lessons whether the modality is face-to-face or an array of emerging remote instructional options. These instructional design processes are unpacking the curriculum standards, designing the events of instruction, selecting instructional materials, and using constructive alignment. This paper is hoped to draw attention to some practices to immediately bring about better responses, thus improve the current work of the teachers and education as a whole.

Funding: No external funding is received for this article.

Declaration of interest: The author declares no competing interests.

Ethics approval and consent to participate: Not applicable.

Availability of data and materials: All data generated or analyzed during this study are available for sharing when appropriate request is directed to the author.

\section{REFERENCES}

Adedoyin, O. B., \& Soykan, E. (2020). Covid-19 pandemic and online learning: the challenges and opportunities. Interactive Learning Environments. Published: 2 September 2020. https://doi.org/10.1080/10494820.2020.1813180

Biggs, J. B., Tang, C., \& Chow, K. (2011). Teaching for Quality Learning at University: What the Student Does. Maidenhead: McGraw-Hill.

Bloom, B. (1956). Taxonomy of Educational Objectives. New York: David McKay.

Bybee, R. W. (2009). The BSCS 5E instructional model and 21st century skills. A commissioned paper prepared for Workshop on Exploring the Intersection of Science Education and the Development of 21st Century Skills. New Zealand: Board on Science Education.

Cahapay, M. B. (2020). A case study of curriculum unpacking practices of a kindergarten teacher. Journal of Curriculum and Teaching, 9(2), 1-8. https://doi.org/10.5430/jct.v9n2p1

Daniel, S. J. (2020). Education and the COVID-19 pandemic. Prospects. https://doi.org/10.1007/s11125-020-09464-3

Donitsa-Schmidt, S., \& Ramot, R. (2020). Opportunities and challenges: teacher education in Israel in the Covid-19 pandemic. Journal of Education for Teaching, 46(4), 586-595. https://doi.org/10.1080/02607476.2020.1799708

Ellington, H. (1987). A Review of the Different Types of Instructional Materials Available to Teachers and Lecturers. Scotland: Scottish Central Institutions Committee for Educational Development. 
Gagne, R. M. (1965). The Conditions of Learning and Theory of Instruction. New York: Holt, Rinehart and Winston.

Hunter, M. (1989). Madeline Hunter in the English classroom. The English Journal, 78(5), 16-18. https://doi.org/10.2307/ 819193

Liguori, E., \& Winkler, C. (2020). From offline to online: Challenges and opportunities for entrepreneurship education following the COVID-19 pandemic. Entrepreneurship Education and Pedagogy, 3(4), 346-351. https://doi.org/10.1177/2515127420916738

Merrill, M. D., Drake, L., Lacy, M. J., \& Pratt, J. (1996). Reclaiming instructional design. Educational Technology, 36(5), 5-7.
Organization for Economic Cooperation and Development (2020). Supporting the Continuation of Teaching and Learning during the COVID-19 Pandemic. Retrieved from https://www.oecd.org/education/

Print, M. (1993). Curriculum Development and Design. Sydney: SRM Production Services.

Sepulveda-Escobar, P., \& Morrison, A. (2020). Online teaching placement during the COVID-19 pandemic in Chile: challenges and opportunities. European Journal of Teacher Education, 43(4), 587-607. https://doi.org/10.1080/ 02619768.2020 .1820981 